\title{
Analysis of the Parties Role on Stabilizing the Lore Lindu National Park Buffer Area (Case Study in Lembah Bada Villages, Lore Barat District, Poso Regency, Central Sulawesi)
}

\author{
Ice Anugrahsari ${ }^{1 \& 5}$, Mustofa Agung Sardjono ${ }^{2}$, Nur Fitriyah ${ }^{3} \&$ Golar $^{4}$ \\ ${ }^{1}$ Post Graduate Program of Forestry Faculty Mulawarman University, East Kalimantan, Indonesia \\ ${ }^{2}$ Forestry Faculty of Mulawarman University, East Kalimantan, Indonesia \\ ${ }^{3}$ Politics and Social Science Faculty of Mulawarman University, East Kalimantan, Indonesia \\ ${ }^{4}$ Forestry Faculty of Tadulako University, Central Sulawesi, Indonesia \\ ${ }^{5}$ Forestry Programme of Agriculture Faculty Muhammadiyah University, Central Sulawesi, Indonesia \\ Correspondence: Ice Anugrahsari, Forestry Programme of Agriculture Faculty Muhammadiyah University, Palu \\ J1. Hang Tuah No.114 Palu 94118 Central Sulawesi, Indonesia Tel. 621-245-394-435. E-mail: \\ iceanugrahsari1985@gmail.com
}

Received: December 4, 2019

Accepted: March 20, 2020

Online Published: April 28, 2020

doi:10.5539/eer.v10n1p8

URL: https://doi.org/10.5539/eer.v10n1p8

\begin{abstract}
The stability of protected areas was influenced by the existence of areas outside it (Meijaard et al., 2006). The more development of the area outside the conservation area, it was necessary to arrange the function of the area to increase the value and opportunities for the use of the area to support development (Kelso et al., 2010). The buffer zone had a very important function, namely to reduce population pressure into conservation areas and nature reserves, provide community economic activities and was an area that allows for sustainable interaction of benefits for the community with conservation areas (Ardhian, 2011). The existence of conservation areas, buffer zones and community economics had a reciprocal relationship that could be beneficial if managed properly (Robinson et al., 2013; and Golar, 2014). This conservation area was increasingly isolated due to exploitative and destructive human activities such as land conversion, encroachment and the resulting increase in human population (Indrawan, 2007; Livawanty et al., 2012; and Golar et al., 2014). A conservation strategy that integrates the uniqueness of resources and the people who live and activities around and within the national park still needs to be explored (Mallombasang, 2012). Abdullah et al. (2013) states that the application of collaboration mechanisms must be followed by safeguards, as a safeguard for its success. One of them was the consolidation of social contracts towards strengthening the buffer zone. The research purposes was to find out the effectiveness of collaboration models that had been applied in overcoming conflicts and find out management strategies through a partnership pattern (process towards social contracts) in an effort to implement collaborative management. This research was conducted in the Lore Lindu National Park area which included 6 buffer villages as samples. The location was determined by consideration as a buffer zone where the community was part of the partnership process. Data analysis was adjusted to the research objectives of qualitative descriptive (in cluster model), fishbone and SWOT analysis. The conclusion was interaction and dependence on various supply of forest resource products that had been going on for generations, and in the end giving birth to positive local wisdom was a major factor in maintaining forest cover in Cluster 1 of Lore Lindu Valley Bada National Park. The experience and learning of collaborative management activities that had been or had been carried out in TNLL were still conventional in nature where community involvement was still mobilized and dominated by BBTNLL management. The non-optimal management of colabotaif in TNLL was dominated by internal factors compared to internal and external factors such as limited resources and access to information, the involvement of stakeholders at the local level which was not yet maximal, the absence or finalization of boundary management, traditional attitudes towards life, and experience bad past in resolving tenure and social conflicts. Global, national and local strategic issues demonstrate the potential for developing collaborative and participatory TNLL management through prospective and competitive Community-based Conservation Partnerships (KKM) in the future. Four important components as a policy strategy that must be carried out based
\end{abstract}


on SWOT in the development of KKM in TNLL were strengthening the legality status of the area through mapping boundaries and preparing participatory zoning, empowering parties, especially local institutions and resources, changing paradigms in resolving tenurial and social conflicts, and developing diversity alternative livelihood sources. Collaborative Management that begins with a social contract in the Community-based Conservation Partnership (KKM) policy, besides having a huge opportunity in overcoming tenurial and social conflicts in the LLNP, also provided certainty and guarantees the sustainability of more equitable and participatory management.

Keywords: buffer zone, lembah bada, KKM, parties role, social contract, SWOT, TNLL, EPASS (Enhancing Protected Area System in Sulawesi), FP3 (Forest Management III)

\section{Introduction}

Forests were also categorized as land areas that need management, use wisely and wisely for the balance of nature for the sake of human survival, ecosystems and biodiversity. In the context of the relationship between forests and communities around forests, (Sardjono, 2004; Schmitz et al., 2012; Wyatt et al., 2013; and Golar, 2014) suggested that the dependence of local communities on forests was not limited to aspects of forest production and forest land, but also the protection function and climate functions that could be used directly or indirectly by local communities in the forest ecosystem. All of that was in the context of maintaining life and increasing their welfare.

Therefore, one of the efforts to anticipate the loss of forest function was to establish a protected area. However, this protected area was not a "panacea", which could solve all problems caused by forest loss. This means that the protected area does not automatically preserve the integrity of the biodiversity found in tropical forests. The state of the ecosystem outside or around it also plays an important role in determining the existence of ecosystems in protected areas. This means that the stability of protected areas was influenced by the existence of areas outside it (Meijaard et al., 2006).

Conservation of forest areas that had a high diversity of flora and fauna, as a habitat for endangered animals, preservation of potential water sources in river basins and forest village community economic resources, among others, were adding and expanding conservation areas. The more development of the area outside the conservation area, it was necessary to arrange the function of the area to increase the value and opportunities for the use of the area to support development.

On the other hand, the interests of the community in increasing their economic capacity also provide opportunities for an increase in the use of illegal forest resources. In order to integrate the economic interests of these communities with the interests of conserving biodiversity and their ecosystems in a balanced way, was to develop buffer zones outside the Natural Preservation Zone (Bismark, 1997; and Kelso \& Jacobson, 2010).

According to Law No. 5 of 1990 concerning Conservation of Biological Natural Resources and their Ecosystems, nature conservation areas were areas that had the function of protecting life support systems, preserving plant and animal diversity, as well as the sustainable use of biological natural resources and their ecosystems. Furthermore, it was stated that the buffer zone was an area outside the nature reserve and conservation area, both as another forest area, state land and land encumbered with rights, which were needed and able to maintain the integrity of the nature reserve and nature conservation area.

Almost all buffer zones, especially in developing countries, had two main functions, namely protecting natural resources within the national park area and as an area that could provide socio-economic benefits for people who live around the national park (Robinson et al., 2013). Thus, the buffer zone had a very important function, namely to reduce population pressure into conservation areas and nature reserves, provide community economic activity and was an area that allows for sustainable interaction of benefits for the community with conservation areas (Ardhian, 2011).

In determining and managing a buffer zone the conservation area must be based on three interrelated aspects, namely ecological, economic, and social cultural aspects of the community, so that the buffer zone had economic value that was able to improve the standard of living and the perception of the community in maintaining the integrity of the conservation area. Therefore, the existence of conservation areas, community economic buffer zones had a reciprocal relationship that could be beneficial if managed properly (Robinson et al., 2013; and Golar, 2014).

Basically the management of the buffer zone was the arrangement of land use and its functions around the national park in order to improve the economy of the surrounding community, which was in accordance with the type of national park ecosystem. Increasing the socio-economic and cultural community around the national park 
will had a positive impact on the environment in terms of regulating the benefits and land use that supports the preservation of the national park system. These efforts must be supported by social safeguard mechanisms, which were supported by participatory government regulations (Abdullah et al., 2013; Pandit et al., 2015).

\section{Literature Review and Theoritical Foundation}

Lore Lindu National Park with an area of 217,991.18 Ha was one of the important National Parks in Indonesia that already had zoning compiled through Management Plans based on the Minister of Forestry Regulation Number: P 56 / Menhut-II / 2006 concerning Park Zoning Guidelines National scale 1: 250,000. The arrangement of the TNLL zone means that the pattern of natural resource utilization could be realized in accordance with the expectations of the government and the community.

The stabilization of the TNLL zoning was nothing but an effort to use natural resources and the environment in accordance with the characteristics of the region itself. For this reason, zoning consolidation was arranged to meet one of the various basic needs in its management.

The management of the TNLL area was faced with a number of problems, the principle of which had commenced since its establishment as a conservation area. The issues referred to include: limited personnel, lack of coordination between agencies, and high pressure on the use of the area in the form of encroachment and theft of natural resources. Many efforts had been made in overcoming this problem, one of which was being developed was a collaboration mechanism.

Collaboration was theoretically considered the most effective form of collaboration. According to Himmelman (1994) in Sardjono (2004), collaboration in addition to being a means of exchanging information, changing activities and contributing resources, also allows increasing the capacity of other parties for mutual benefit and in order to achieve common goals.

Various studies in the LLNP had recently shown that these conservation areas were increasingly isolated due to exploitative and destructive human activities such as land conversion, encroachment and the effects of human population growth (Indrawan, 2007; Livawanty et al., 2012; and Golar et al., 2014).

In TNLL, various efforts had been made by related parties in efforts to overcome these problems, including a government program known as the Central Sulawesi Integrated Conservation and Development Program (CSICDP) which focuses on ecological and biodiversity studies alone. However, this program had not yet accommodated community involvement (Mappatoba, 2004). The next effort was a conservation program through community empowerment was the Community Conservation Agreement (KKM) carried out by The Nature Conservacy since 2002. Even though the real results of this program could be seen as reported by Mappatoba (2004) with community empowerment through co-management mechanisms; Berdej (2011) with cooperation and communication between institutions, but a conservation strategy that integrates the uniqueness of resources and the people who live and activities around and within national parks still needs to be explored (Mallombasang, 2012).

The most recent study, carried out by Abdullah et al. (2013) related to the collaborative mechanism of national park management concluded that the application of collaboration mechanisms must be followed by safeguards, as a safeguard for its success. One of them was the consolidation of social contracts towards strengthening the buffer zone. A number of studies were needed to make this happen.

Based on this description, several important questions were formulated as a basis for this research, as follows how were the dynamics of land use pressure in the LLNP over the past 10 years, how effective were the collaboration models that had been applied in the context of resolving conflicts in Lore Lindu National Park and how were the models conflict resolution through a partnership process (towards social contracts) in an effort to implement collaborative management.

Referring to the research questions as described above, the purpose of this study was to describe and analyze the dynamics of pressure on the Lore Lindu National Park for a period of 10 years; describe and analyze the effectiveness of collaboration models that had been applied in overcoming conflicts in the Lore Lindu National Park and describe and analyze management strategies through partnership patterns (processes leading to social contracts) in implementing collaborative management.

The results of this study were expected to be used by the government and other parties in the management of this area in the future, namely the results of the research were expected to add scientific information related to efforts to manage natural resources in conservation areas, as a reference for managers and policy makers (the Government) in formulating collaborative strategies for the management of conservation areas and providing direction for the community in efforts to protect, preserve and utilize the area through collaborative management. 


\section{Method}

\subsection{Study Area}

This research begins with the collection of secondary and primary data, in this study it took 6 months (starting in November 2017 to May 2018) and data management and preparation or writing of a new dissertation began in 2019 until now. This research was conducted in the Lore Lindu National Park area which includes buffer zones, from 37 buffer villages there were 6 buffer villages that were targeted by researchers. The location was determined by consideration as a buffer zone where the community was part of the partnership process.

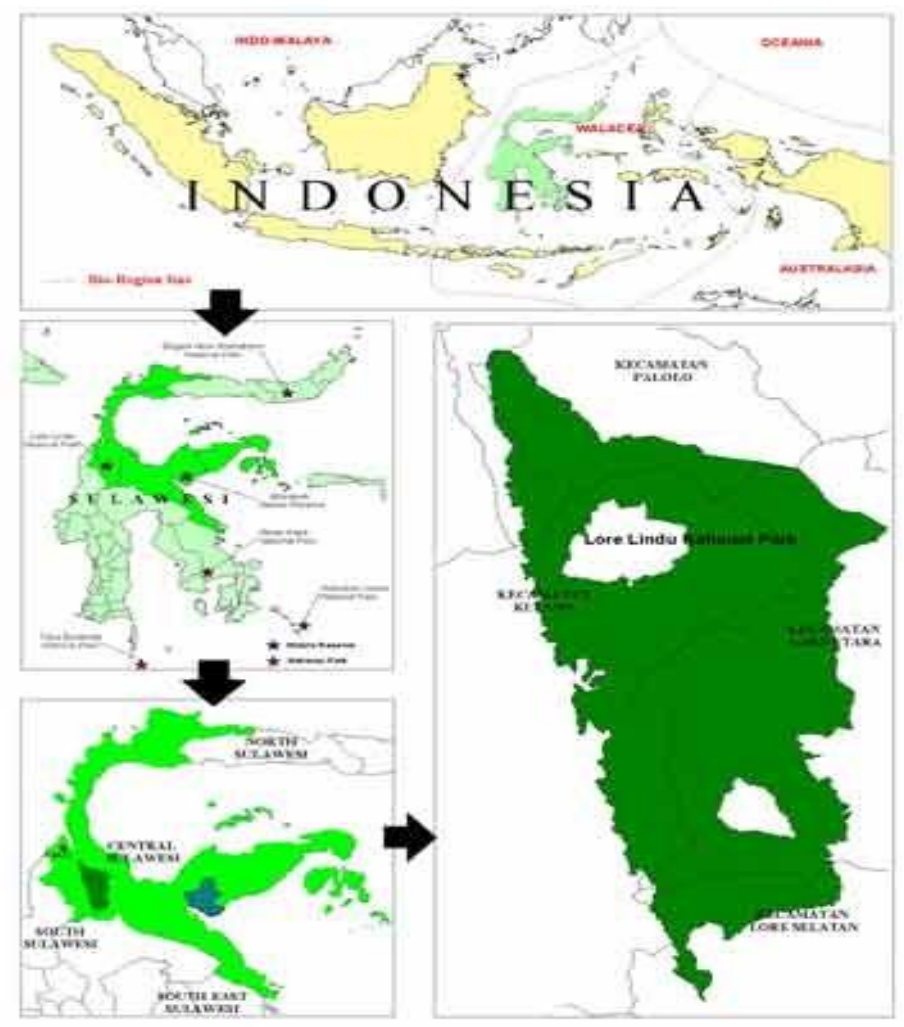

Figure 1. Research location

\subsection{Tools and Materials}

Materials and tools used in this study were questionnaires and form formats, for gathering information from respondents and other data sources from observations; other supporting materials and equipment such as tape recorders, to record conversations with respondents; tools and materials for writing, used to record the observed object of research; photo camera to record observation objects, especially important objects that were selected and displayed in the results of this study; computers and accessories, used for data processing and report preparation.

\subsection{Data Collection}

The data collected in this study consisted of primary data, namely data from observations, interviews and secondary data obtained from relevant agencies. The primary data collected consists of data on the utilization of the Lore Lindu National Park area by the community which includes the type and location of potential forest resources used, partnership data that was data related to the formation of partnerships (the process of forming social contracts) and other related information, policy data, plans and programs established in partnership as part of the area management and community empowerment program.

Secondary data collected was data on the general condition of the study site which includes data related to physical conditions (climate, geology, soil, hydrology) biological conditions (potential for vegetation and wildlife) and socio-economic and cultural conditions of communities around the area to be obtained from the Central Office of the National Park Lore Lindu and related institutions.

\subsection{Data Analysis}

Primary and secondary data that had been processed and analyzed using various techniques in accordance with the 
objectives of this study, namely according to the purpose of the first study outlines the dynamics of pressure on the lore lindu national park area over a span of 10 years. The purpose of this study was described using qualitative descriptive analysis. The second objective was to determine the effectiveness of collaboration models that had been applied in overcoming conflicts in the Lore Lindu National Park. Objective three was to find out management strategies through partnership patterns (processes leading to social contracts) in the effort to implement collaborative management. The purpose of this study used a SWOT analysis.

\section{Result and Discuccions}

\subsection{Model Approach Taken}

Various collaborative activities within the framework of partnership between BBTNLL and the community in West Lore District had been carried out. This activity was intended as a form of awareness and opportunity for BBTNLL to be able to interact with the community in and around TNLL. The forms of approaches that had been carried out include:

a. Boundary of the TNLL area; The TNLL boundary demarcation process had been carried out consultatively since 2006. The parties considered important to be involved were all involved maximally in the boundary delineation process. The boundary process was also carried out consultatively which was supported by TNLL partners). The results of the consultative boundaries were outlined in the proposed outer boundaries and TNLL zoning.

b. Zoning Area Arrangement; The activity was intended to obtain participatory spatial planning within the TNLL area. The activity began with Participatory Village Mapping (PDP) with TNLL partners. The results of participatory village mapping activities in the form of community land classification were land use that will be the basis for the preparation of TNLL zoning. The land classification. were (a) residential areas, (b) agricultural land, (c) pasture and livestock grazing, (d) forest areas (limited, daily use, and customary forest), (e) historic / cultural sites. Based on the concepts and practices of the use of natural resources by indigenous peoples in the LLNP, 3 zonation types were recommended, namely the core zone, the traditional use zone and the special zone so that it was more easily understood and obeyed by the communities themselves. Based on the Minister of Forestry regulation number P.56 / Menhut-II / 2006 regarding the National Park Zoning Guidelines, the zones in the national park consist of a minimum of core zones, jungle zones, and use zones, then there were other zones (traditional zones, rehabilitation zones , religious-historical-cultural zone, and special zone). The Minister of Forestry also said that at least the national park must had a core zone, jungle zone, and use zone. The zoning of national parks was based on the potential and function of the area by taking into account ecological, social, economic and cultural aspects.

c. Forest Police Volunteers (Pamswakarsa); was a program to support BBTNLL in the formation of voluntary forest security personnel (Pam Swakarsa). Its membership was the alocal community recruited for regular security and monitoring / patrol services in the TNLL area.

d. Partnership Activities by TNLL Partner agencies; BTLL built a partnership process with the community, one of which was by involving donor partners and non-government organizations. Activities with partners include TNC, FP3, EPAS carried out in several locations within the TNLL area to strengthen the management of TNLL that was more participatory, equitable and sustainable.

\subsection{Effectiveness and Learning}

The process of building collaborations and partnerships that had been carried out and occurring in TNLL generated a lot of learning, including:

a. The interests of conservation and community welfare were not yet integrated. The activities carried out through interaction with the community gave rise to the perspective that the management of conservation areas, in this case the TNLL, could not be separated by increasing community welfare. The interests of conservation must be in line with the interests of the needs of community life in and around the area.

b. Barriers to communication and perspective of regional development within conservation areas. There were still conflicting policies between the Central and Regional Governments, for example to open isolated areas (road building), in the process of demarcation, road construction, regional development and natural resource utilization. This shows that it was not yet integrated between conservation interests and regional development.

c. Barriers to communication and decision making. In implementing multistakeholder activities, structural decision-making needs were often encountered. Decisions at the central level especially the Ministry of Forestry sometimes take a long time to cause suspicion at the community level, for that the working 
relationship between the central, regional and field level must be coordinated and agreed upon follow-up which was well communicated and carried out in a timely manner.

d. Organizational and institutional coordination and collaboration at the site (district and provincial) level was still weak. One obstacle that was often raised was the limited funds both at central and regional levels, as well as inadequate human resources. The TNLL Business Plan as an alternative to realize the independence of national park management funding, bearing in mind that there was no guarantee of sustainable funding.

e. Disclosure of biodiversity richness as well as socio-cultural community which must be considered in the management of TNLL. Through the process of facilitation and activities carried out by TNLL partners, many potential biodiversity and socio-cultural potentials were revealed to be the comparative advantages as well as the pride of TNLL.

f. Foster mutual trust between the parties in the LLNP. The process of interaction between TNLL managers, partners and the community was a process that requires a long time. Through communication strategies and more intensive patterns of interaction between the parties, ultimately fostering mutual trust, the emergence of shared ideas, the needs and interests of the parties that must be accommodated.

g. Awareness of the importance of social, economic and cultural aspects in managing the LLNP. Building community awareness in TNLL management participation requires strong foundation support for the important social, economic and cultural aspects of the communities surrounding the TNLL area. The social, economic and cultural benefits of the existence of the TNLL in particular the support of alternative economic development and environmental services were able to conserve natural resources and their ecosystems

h. Institutional support, roles and responsibilities of the parties. In collaborative management, even though in writing there was already an agreement on roles and responsibilities, but often it cannot be realized maximally in management operations. Concrete institutionalization through strengthening community institutions and contributing to local governments was an important requirement in the operations of TNLL management.

i. The importance of field trips and direct dialogue at the local level. This activity was very important in increasing the understanding of the parties in the Ministry of Environment and Regional Government to get a better understanding of the reality at the TNLL site level.

j. Development of creative funding mechanisms and concrete collaboration. Building TNLL collaboration management requires a lot of time and capital in the formation and implementation. The management of the TNLL collaboration had the complexity of a multi-stakeholder arrangement and high travel costs, so it was necessary to develop a creative funding mechanism and concrete ongoing collaboration.

k. The development of accommodative and participatory collaborative management policies requires awareness, care and recognition of all major parties in the LLNP. Decisions taken in collaborative management must had full power that had fulfilled the interests of all parties in the TNLL area. So that TNLL was recognized for its existence by all parties.

1. Collaboration must be preceded by social agreements at the site level, that is, people who had actually lived, grown and developed for generations and had had longer and more real interactions with TNLL. Collaboration and social agreements were key to ensuring fair and sustainable management of the TNLL area.

\subsection{Management Strategy}

Analysis of strategic issues was an important and crucial part in the process of preparing a LLNP collaborative management plan to complete the stages that had been carried out previously. Identification of appropriate and strategic issues increased the acceptability of management priorities, could be operationalized and morally and institutional ethics could be accounted for. Management planning, among other things, was intended to ensure that TNLL's institutional services were always able to align with the environment and the aspirations of the community in and around TNLL and service users in TNLL. Therefore, attention to the mandate of the community and its external environment was external planning that must not be ignored.

Strategic issues related to the management of TNLL come from internal analysis in the form of identification of TNLL management problems and external analysis in the form of conditions that create opportunities and threats for TNLL management in the future. Based on the study of internal and external aspects of the strategic issues of TNLL management were presented in the following table: 
Table 1. Identification of strategic issues (external and internal environments)

\begin{tabular}{|c|c|c|c|}
\hline \multicolumn{4}{|c|}{ Strategic Issues } \\
\hline \multicolumn{2}{|c|}{ Aspect (Dinamica) External } & \multicolumn{2}{|c|}{ Aspect (Dinamica) Internal } \\
\hline $\begin{array}{l}\text { International } \\
\text { (1) }\end{array}$ & $\begin{array}{c}\text { National } \\
(2)\end{array}$ & $\begin{array}{c}\text { Regional/Local } \\
(3) \\
\end{array}$ & $\begin{array}{c}\text { Local/Peoples } \\
(4) \\
\end{array}$ \\
\hline $\begin{array}{l}\text { The issue of Climate Change } \\
\text { and Global Warming which } \\
\text { had become a concern and } \\
\text { demand of the international } \\
\text { community to reduce } \\
\text { greenhouse gas emissions } \\
\text { from land use and improved } \\
\text { forest governance }\end{array}$ & $\begin{array}{l}\text { The commitment of the Indonesian } \\
\text { government to contribute to national } \\
\text { GHG emission reduction by } 29 \% \\
\text { independently and } 41 \% \text { with } \\
\text { international support, as well as } \\
\text { support for the contribution of } \\
\text { conservation areas in REDD + }\end{array}$ & $\begin{array}{l}\text { Central Sulawesi and the existence } \\
\text { of TNLL as one of the Provinces } \\
\text { and at the same time a priority } \\
\text { national park to contribute } \\
\text { nationally to the issue of climate } \\
\text { change }\end{array}$ & $\begin{array}{l}\text { Facilitation of programs in the } \\
\text { community-based TNLL by } \\
\text { TNLL partners who supported } \\
\text { collaborative management and } \\
\text { climate change adaptation and } \\
\text { mitigation at the site level }\end{array}$ \\
\hline $\begin{array}{l}\text { Demands for the } \\
\text { management of conservation } \\
\text { areas, especially national } \\
\text { parks that were more } \\
\text { participatory, adaptive and }\end{array}$ & $\begin{array}{l}\text { The commitment of the Government } \\
\text { of Indonesia to implement } \\
\text { collaborative conservation area } \\
\text { management with stakeholders, } \\
\text { especially the community }\end{array}$ & $\begin{array}{l}\text { The existence of TNLL as one of } \\
\text { the custom-based NPs and } \\
\text { biosphere reserves highlights the } \\
\text { importance of collaborative } \\
\text { management }\end{array}$ & $\begin{array}{l}\text { The existence of indigenous } \\
\text { peoples in and around the TNLL } \\
\text { provides important value for } \\
\text { participatory and collaborative } \\
\text { TNLL management }\end{array}$ \\
\hline collaborative & $\begin{array}{l}\text { Conflicts in various conservation } \\
\text { areas had an impact on Indonesia's } \\
\text { image in the management of } \\
\text { conservation areas }\end{array}$ & $\begin{array}{l}\text { The management of TNLL and the } \\
\text { support of Local Government in } \\
\text { overcoming conflicts in } \\
\text { conservation areas provided } \\
\text { regional and national learning }\end{array}$ & $\begin{array}{l}\text { Tenure conflicts and local } \\
\text { conflicts had an impact on the } \\
\text { performance and low social } \\
\text { perceptions / performance of } \\
\text { TNLL managers }\end{array}$ \\
\hline $\begin{array}{l}\text { The development of } \\
\text { environmental services, } \\
\text { especially ecotourism as an } \\
\text { alternative to natural } \\
\text { attractions and interests }\end{array}$ & $\begin{array}{l}\text { Policy support for the development of } \\
\text { tourism and the creative economy }\end{array}$ & $\begin{array}{l}\text { The appointment of TNLL as one } \\
\text { of the priority natural tourism } \\
\text { destinations in Sulawesi }\end{array}$ & $\begin{array}{l}\text { Local natural tourism industry } \\
\text { began to develop in demand }\end{array}$ \\
\hline \multirow[t]{3}{*}{$\begin{array}{l}\text { The international spotlight on } \\
\text { the rights of indigenous } \\
\text { peoples and development } \\
\text { affected communities }\end{array}$} & $\begin{array}{l}\text { The policy of granting access and } \\
\text { legal community management in } \\
\text { several community-based forest } \\
\text { management schemes such as HKm, } \\
\text { HD, HTR, HA and partnerships } \\
\text { (forestry. Conservation) }\end{array}$ & $\begin{array}{l}\text { There was a commitment from } \\
\text { BBTNLL and the local government } \\
\text { to implement collaborative TNLL } \\
\text { management in a conservation } \\
\text { partnership scheme with the } \\
\text { community }\end{array}$ & $\begin{array}{l}\text { There was support and } \\
\text { incentives from TNLL partners } \\
\text { and communities around TNLL }\end{array}$ \\
\hline & $\begin{array}{l}\text { Implementation of FPIC / Rice and } \\
\text { policies on the use of safeguards in } \\
\text { the management of forests related to } \\
\text { indigenous / local communities }\end{array}$ & $\begin{array}{l}\text { The tenure conflict was still high in } \\
\text { the use and use of land in the } \\
\text { forestry sector, and the } \\
\text { implementation of FPIC / FPIC } \\
\text { was not yet optimal }\end{array}$ & $\begin{array}{l}\text { Conflicts over boundaries and } \\
\text { spatial use within the LLNP } \\
\text { were still present and FPIC / } \\
\text { FPIC socialization was not } \\
\text { optimal }\end{array}$ \\
\hline & $\begin{array}{l}\text { Decision of the Constitutional Court } \\
35 / 2012 \text { Concerning Customary } \\
\text { Forests which mentions customary } \\
\text { forests were no longer state forests (in } \\
\text { forest areas) }\end{array}$ & $\begin{array}{l}\text { Increased demand for accelerated } \\
\text { recognition of forest areas and the } \\
\text { recognition and protection of } \\
\text { indigenous peoples }\end{array}$ & $\begin{array}{l}\text { The absence of identification and } \\
\text { inventory of customary forests } \\
\text { and legality as a reference / } \\
\text { reference in the regions }\end{array}$ \\
\hline
\end{tabular}

\subsection{Internal and External Factor Analysis}

Identification of the internal and external environment was needed to find out how much strength the community had that could be utilized to overcome existing weaknesses by taking advantage of opportunities outside and minimizing threats that exist outside the TNLL community.

Based on the analysis conducted, in the internal environment, there were strength and weakness factors. Because they were internal, all these strengths and weaknesses were within the capacity of the community to change or influence them. Identification of internal factors had been carried out through factor analysis techniques and brainstorming to identify a number of abilities and internal resources that could be relied on in achieving its goals and objectives. Identification could also be done by observation or document review. The results of the identification were grouped into categories of strengths and weaknesses. Potentials and abilities, which were 
owned by the TNLL community, were categorized as strengths, while the limitations and weaknesses that exist in the community were categorized as weaknesses.

From the identification of external factors, it was known what potentials exist outside the TNLL community to be utilized and developed, which will then be categorized as opportunities for the community to be able to exploit them. In addition, external factors could be in the form of threats that will be able to hamper the progress of TNLL management.

\subsubsection{Internal Condition Analysis}

In the analysis of internal conditions, the strengths and weaknesses of the TNLL were as follows:

a. Strengths consist of: Legal status as TN Lore Lindu; Potential ecosystems, biodiversity and attractions in the LLNP; Commitment of Local Government and Donor partners to work in TNLL; There was a legal basis for forming collaboration in the management of TNLL; The existence of indigenous peoples in the LLNP which was known nationally and internationally

b. Weaknesses include: History of past conflicts; Inauguration of the zone zoning had not been completed; Limitations on the quantity and quality of human resources, as well as the facilities and infrastructure of the TNLL Office; Institutional and Partner activities had not been effective; Not yet optimal support, coordination and communication of the parties, especially partners in the regions.

\subsubsection{External Condition Analysis}

a. Opportunities include: Collaboration with Donor Partners in managing and funding TNLL; Collaborative collaboration and facilitation with TNLL partner institutions on various themes and issues of indigenous peoples; The appointment of Central Sulawesi in particular the TNLL as an important region to support the contribution of reducing greenhouse gas emissions and world heritage biosphere reserves; The development of natural tourism specific to indigenous peoples; Availability of regulations for collaborative management

b. Threats include: The issues of radicalism and social conflict; Excessive spotlight and views on tenure conflicts and the existence of indigenous peoples in and around the LLNP; Access and mobility of residents from outside the TNLL area; Increased encroachment, illegal logging and illegal mining.

Based on the identification of internal factors and external factors were then arranged in a SWOT matrix. The SWLL Management Matrix matrix was presented below:

Table 2. SWOT analysis matrix and external / internal factors

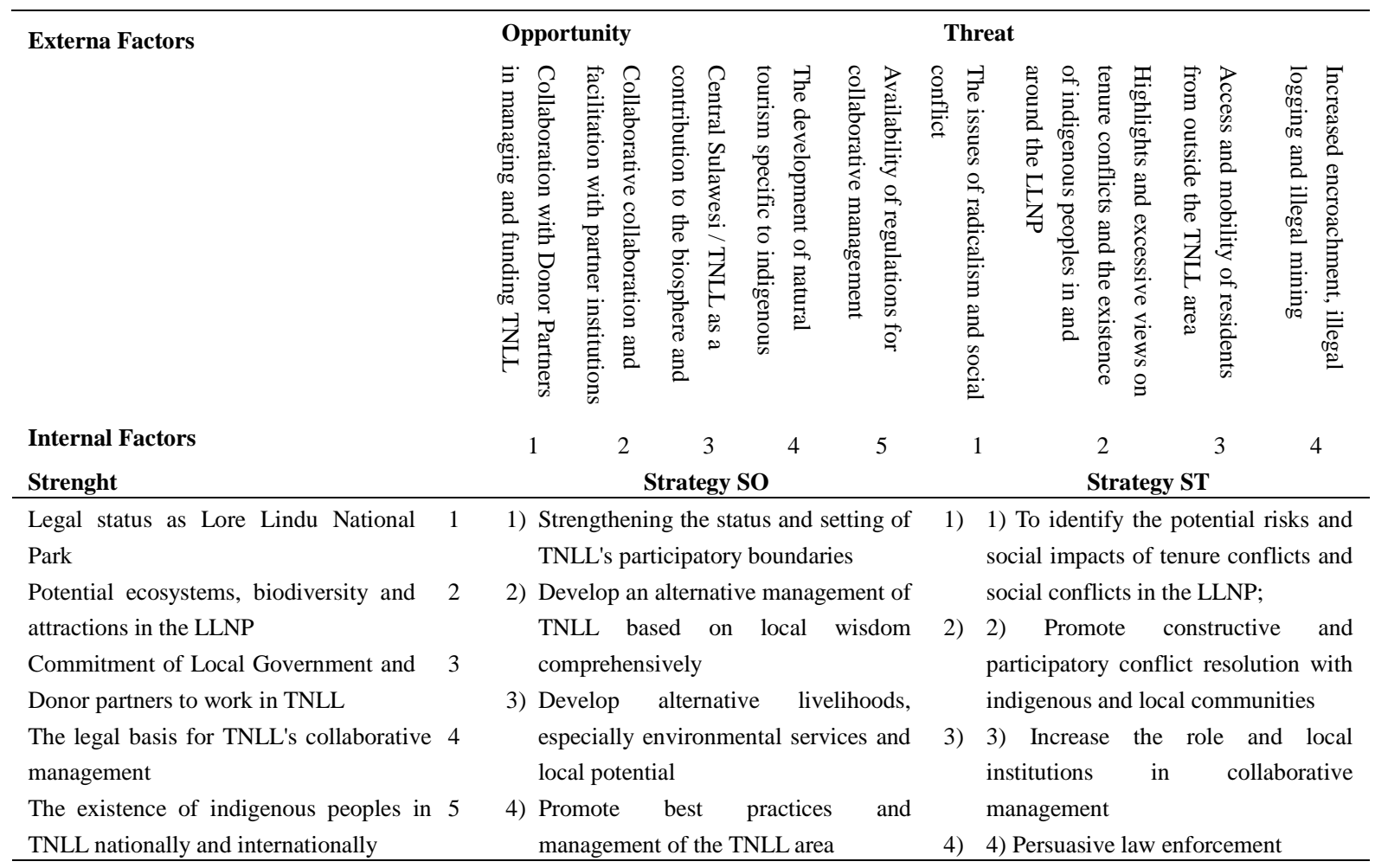




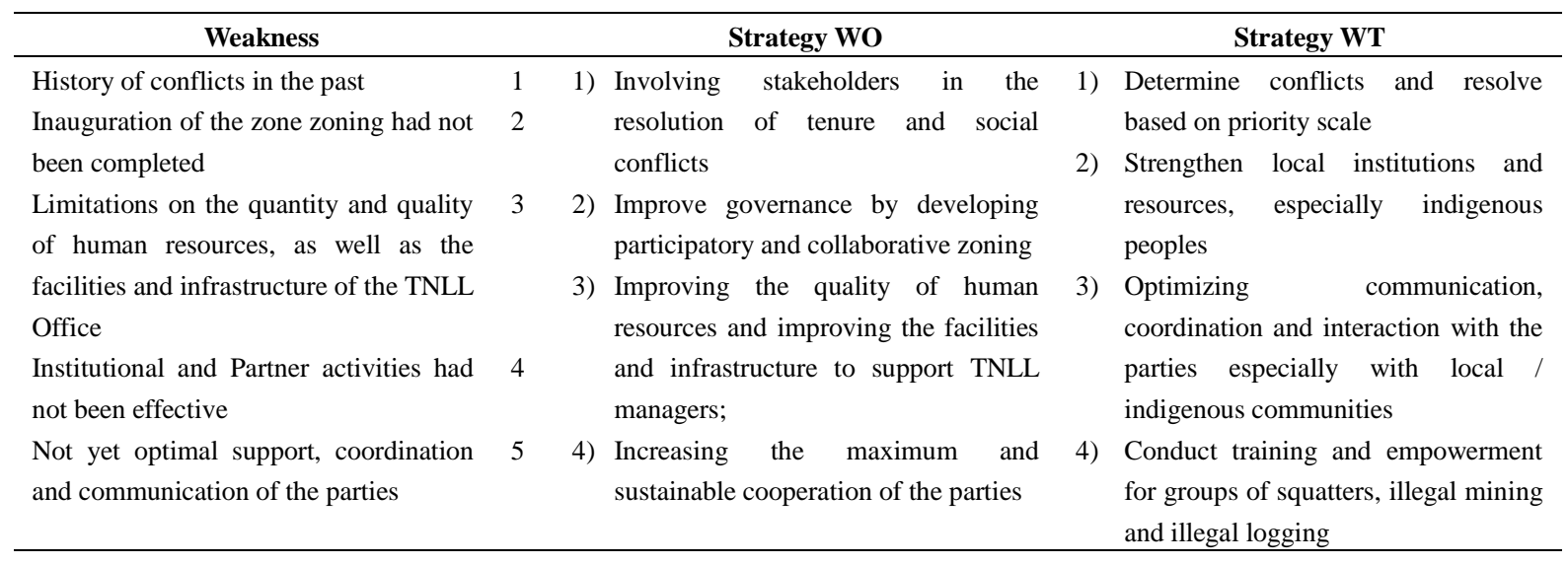

\subsection{Role Analysis of the Parties}

The management of TNLL in the future collaborative partnership scheme brings the consequences of the division of authority and responsibility based on the interests of the parties (stakeholders). If the Partnership program was implemented and implemented, then an institutional process and mechanism in managing the partnership area was absolutely necessary. Existing institutions were ideally multistakeholder, and for this purpose identification of the parties (takeholders) directly or indirectly related to the existence and partnership activities in the LLNP needs to be done beforehand.

Based on the results of identification and analysis of interested stakeholders, the parties involved as key stakeholders in the TNLL could be distinguished from individual stakeholders, namely individuals from internal surroundings or from outside TNLL, and stakeholder groups (groups) in the form of institutions, organizations or agencies that originate from inside or outside TNLL. Each stakeholder (individual and group) was classified based on involvement in future management issues, namely into three groups namely: (1). Direct Primer; (2). Indirect Primary; and (3). Secondary;

Direct primary groups were stakeholders who were directly involved in managing the Partnership area and / or had a direct impact on management in the future. Indirect primary groups were stakeholders who were indirectly involved in managing the partnership area, but benefit directly from conservation activities that will take place later. Whereas the secondary group was stakeholders who were not directly involved in managing the Partnership area and do not benefit directly from the management of the Partnership area.

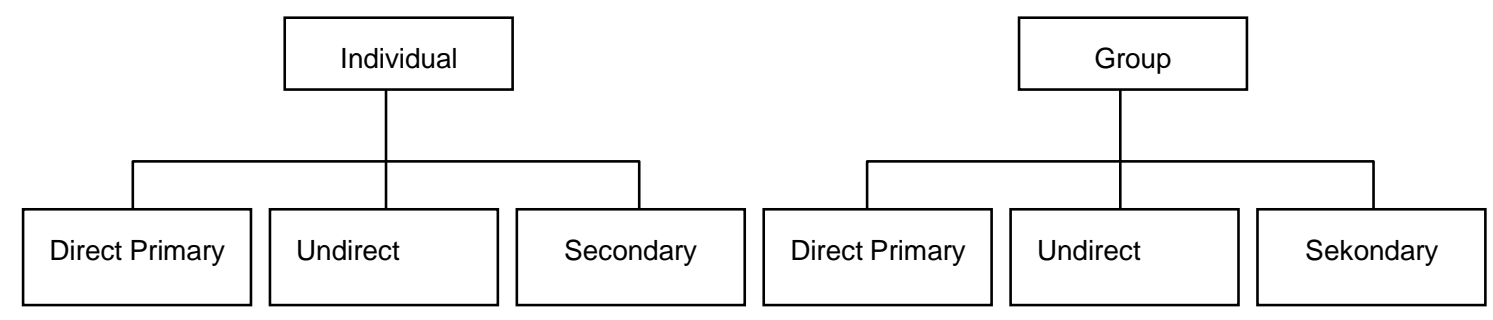

Figure 3. Scheme of individual and group stakeholders classification

\subsubsection{Individual Stakeholder Identification}

The following were the Individual stakeholders who had been identified based on their main interests in the TNLL Conservation Partnership, which could be detailed as follows:

\subsubsection{Direct Primary Individual Stakeholders}

a. Governor; as head of the Central Sulawesi Provincial Government, the Governor had an interest in the management of the TNLL area, especially in regional and community development which was administratively located in the area of Central Sulawesi Province.

b. The Regent; in this case the Regents of Poso and Sigi Regencies where the LLNP region was located in the two regencies. As head of the Regional Government, the Bupati had an interest in the management of TNLL, where 
the community and administrative services require regional development policies.

c. BBTLL Head; as the representative of the Central Government in the management of TNLL, the Head of BBTNLL had a direct role in the management of the TNLL area;

d. Camat; Especially in sub-districts where the area was directly related to the LLNP, a subdistrict head had an administrative interest in facilitation and guidance that will be carried out in the TNLL partnership area management activities;

e. Village Head; As the highest leader and representative of the Government at the village / village level, the Village Head had an interest in the direct benefits of TNLL management especially the Partnership area for the prosperity of his village residents.

\subsubsection{Indirect Primary Individual Stakeholders}

a. Religious Figure; The attitude of religious communities in and around the LLNP was very high. Therefore the role of religious leaders at various levels up to the village was very important. A religious leader had an interest in the attitudes and behavior of rural communities who support the sustainability of the Partnership's area;

b. Teacher; As educators and educators, teachers play an important role in providing education and teaching towards the attitudes and behaviors of students as young people who support the preservation of forests and natural resources including the TNLL area;

c. Extension agents; As a government employee who directly interacts with the community, the healer had a role in influencing and changing the attitude of the community in the village. The interaction which was quite intense in terms of counseling, facilitation and assistance of villagers, provides a significant opportunity for extension workers to provide positive things to residents, including the importance of supporting the sustainability of natural resource management and partnerships.

d. Village Local Assistance; As a mentor from the PMD Office of the Ministry of Villages and Disadvantaged Areas, local assistants play an important role in village development. The role of local village facilitators was mainly in advocating and facilitating the preparation of Village Budget and Revenue which could be optimized for natural resource management and environmental sustainability.

\subsubsection{Secondary Individual Stakeholders}

Secondary individual stakeholders in this activity were identified primarily as employees at BBTNLL, workers and conservation program staff (NGOs, Donor Partners). These employees and workers play an important role in providing input to the policies in their place of work to support the preservation of the functions and benefits of the TNLL area. Details of identification of individual stakeholders could be seen in the following table:

Table 3. Identification of individual stakeholders based on main interests

\begin{tabular}{|c|c|c|}
\hline No & Individual Stakeholders & Main Interests \\
\hline \multirow[t]{6}{*}{1.} & Direct Primary & \\
\hline & Governoor & Regional Development and citizen administration services \\
\hline & Head Regency & Regional Development and citizen administration services \\
\hline & BBTNLL Head Officer & Central Government Representative in the authority to manage conservation areas \\
\hline & Head Sub Regency & Guidance and services for villagers in the subdistrict administration area \\
\hline & Head Village & Development and ensure direct benefits for villagers \\
\hline \multirow[t]{5}{*}{2.} & Undirect Primary & \\
\hline & Religious leaders & Build and maintain the attitudes, behavior and spirituality of citizens \\
\hline & Teacher & Building positive values through education for school students \\
\hline & Extension Worker & Provide understanding and positive values in improving the welfare of citizens \\
\hline & PLD staff & $\begin{array}{l}\text { Advocacy, facilitation and assistance in optimizing the Regional Budget for the } \\
\text { management of natural resources and the environment }\end{array}$ \\
\hline \multirow[t]{3}{*}{3.} & Secondary & - \\
\hline & Staff BBTLL & Support and facilitation \\
\hline & Conservation program workers / employees & Support, facilitation and advocacy \\
\hline
\end{tabular}

\subsubsection{Identification of Group / Institution / Institutional Stakeholders}

In the case study in the management of the TNLL area, the identified stakeholder groups could be detailed as 
follows:

\subsubsection{Direct Primary Group / Institution / Institutional Stakeholders}

a. Ministry of Environment and Forests; through the Director General of KSDAE, plays a direct role as the authority of state-owned forest areas which were currently managed in the TNLL area by BBTNLL;

b. Vertial Institutions of the Ministry of Environment and Forests; in this case the BPKH and BP-DAS who play an important role as vertical agencies of the LHK ministry in demarcating and managing watersheds in the LLNP;

c. Central Sulawesi Forestry Service; Its authority was directly under the authority of the Province, with implementation at the site level below the FMU. Administratively, the KPH that plays a role in the authority of forest management in the Segah da Kelay area, including in Batu Rajang Village, was the West Berau KPH.

d. Regional Development Planning Agency; This institution was directly authorized to provide planning directions in the use of space and land use relating to resource management in accordance with the vision of the development of Central Sulawesi Province;

e. TNC (The Nature Conservancy), and UNESCO .; This institution was a program run by an institution formed in cooperation with Indonesia with a donor donor to maintain and improve forests and climate change in the forest areas in Sulawesi. As agreed, the institutions for this program carried out many activities, work implementations and plans for the collaborative initiative. In TNLL TNC and Unesco worked a lot for community empowerment within the framework of forest conservation and reduction of degradation and deforestation in the TNLL region;

f. Village Government; was the smallest formal government institution that was directly located and interacts with the community. Village Government involvement directly in managing the LLNP Partnership was as a partner and communication bridge with TNLL managers and other partners. In addition to carrying out direct management, the village government will also carry out direct activities in the form of security, protection and preservation in cooperation with the apparatus and other institutions at the village level.

g. Farmer Groups; were direct users and users of the TNLL management partnership program. Their well-being could be an indicator of community empowerment and the sustainability of forest resources in the LLNP;

h. Timber or non-timber Forest Product Collecting Group; Although this group was not large in number, it plays an important role in the management of forest areas in the future because they were direct beneficiaries.

\subsubsection{Indirect Primary Group / Institution / Institutional Stakeholders}

a. Plantation Service (provisni and regency); Institutionally, the Estate Crops Office had an interest in developing village community plantation products within the TNLL area. Plantation commodities, especially coffee and cocoa, require facilitation and development from relevant agencies;

b. Mining Service; The Mining Department was very interested in ensuring that illegal and surrounding mining sites within the LLNP could be overcome, so that no further conflict and encroachment occurs;

c. Animal Husbandry Service; had an interest in developing the livestock sector in villages within the LLNP. In the TNLL the potential for cattle and pig farming was an alternative source of livelihood that should be developed;

d. Tadulako University; In accordance with the mission of the tertiary institution, Tadulako University had an interest in conducting research and development within the conservation area.

e. Community non-governmental organizations, having an interest in facilitation, advocacy and other efforts related to issues of sustainable forest management, sustainable agriculture,. These institutions include the JAMBATA Foundation, KARSA, AG (Awam Green), the Ngata Toro Indigenous Women's Organization (OPANT), the LOHENA organization, STORMA-UNTAD, TNC (The Nature Conservancy), and UNESCO.

\subsubsection{Secondary Group / Institution / Institutional Stakeholders}

a. Middlemen from the plantation and gold mine; Although the TNLL area was a conservation area, land use activities for plantations and mining were common. The group of middlemen and buyers of estate crops and gold need to be involved in supporting conservation and 'green' programs as a return or incentive for the management of the TNLL area;

b. Press / Journalist; With the existence of resource conflicts, the area management model, and the existence of the partnership model in forest watch, it becomes an interesting topic in media coverage, both print and 
electronic, starting from the local, national and even international level;

c. Developers of traveling and nature tourism; could be directly involved in the management of TNLL because of its importance in the preservation of ecosystems, culture and positive values in TNLL. The development of environmental services for ecotourism in the TNLL region, especially in rural areas, could be supported by the existence of cultural values that develop from the surrounding community, so that the development of ecotourism could be integrated and had a positive impact on the surrounding community;

d. Provincial and Regency DPRD; In many cases the DPRD had an interest in controlling and supporting Local Governments, related to budgeting policies for development and management in the TNLL partnership area;

e. Security forces (Polres); Polres and Polsek security forces could play a role in resolving land conflicts, encroachment, illegal mining and illegal logging that often occurs in the LLNP. Conflict had the potential to negatively affect the management of the TNLL area. Land use claims that increase with the opening of access and illegal mining in the LLNP were feared to had implications for the partnership program;

f. The parties identified based on the main interests related to the Partnership will be distinguished again based on the interests of interest and influence on the management of the TNLL area.

\subsection{Sustainability Strategy Agreement for Community Partnerships Through Social Contracts}

Collaborative management was a solution that was expected to solve problems that had occurred since 2000 in the Lore Lindu National Park. Collaboration begins with building an understanding between stakeholders involved in the management of TNLL. In this case the success of collaborative work could be achieved if the development of the same view (coomon ground) between stakeholders, the recognition of each stakeholder and collective agreement in the management of TNLL.

The Community Partnership Agreement or currently known as the Joint Community Conservation Partnership (KKM) in West Lore District was one of the priorities in collaborative management in the LLNP. The KKM in West Lore District was a strategic step to accommodate the local wisdom of the community while minimizing the impact caused by encroachment around the LLNP. The participation and support of local / customary communities must be developed through social agreements in the form of social contracts that demonstrate the rights and obligations of each party. Efforts to empower and improve the capacity of each party were an important priority in building the agreement.

\section{Conclusion}

Based on the results of the analysis and discussion previously described, the following conclusions were obtained as follows interactions and dependence on various supply of forest resource products that had lasted for generations, and in the end gave birth to positive local wisdom which was the main factor in maintaining forest cover in Cluster 1 Lore Lindu Valley Bada National Park. The experience and learning of collaborative management activities that had been or had been carried out in TNLL were still conventional in nature where community involvement was still mobilized and dominated by BBTNLL management. The non-optimal management of colabotaif in TNLL was dominated by internal factors compared to internal and external factors such as limited resources and access to information, the involvement of stakeholders at the local level which was not yet maximal, the absence or finalization of boundary management, traditional attitudes towards life, and experience bad past in resolving tenure and social conflicts. Global, national and local strategic issues demonstrate the potential for developing collaborative and participatory TNLL management through prospective and competitive Community-based Conservation Partnerships (KKM) in the future. Four important components as a policy strategy that must be carried out based on SWOT in the development of KKM in TNLL were strengthening the legality status of the area through mapping boundaries and preparing participatory zoning, empowering parties, especially local institutions and resources, changing paradigms in resolving tenurial and social conflicts, and developing diversity alternative livelihood sources. Collaborative Management that begins with a social contract in the Community-based Conservation Partnership (KKM) policy, besides having a huge opportunity in overcoming tenurial and social conflicts in the LLNP, also provides certainty and guarantees the sustainability of more equitable and participatory management.

In accordance with the results of research and conclusions that the author had suggested, the authors provide suggestions such as efforts to maintain, preserve and develop the customs, traditions and cultural heritage in the management of natural resources as local identities that support the management of TNLL as well as local social icons in TNLL needs to continue to be developed and legalized. Improving governance through mapping and spatial planning of village areas was an alternative and solution in starting the development of Community 
Conservation Agreements in the LLNP starting with social contracts. Cooperating, effective communication and good cross-sectoral synergy between government agencies / organizations at the central and regional levels, as well as between the parties involved in managing TNLL in developing TNLL Management as an icon and pride of Central Sulawesi. Developing more attractive and attractive destinations and variations of ecotourism activities through the development of social tourism based on culture, customs, development of science tourism based on research and knowledge activities, and development of specific tourism (Specific tourism) based on special interests such as adventure, culinary, outbound, and others as an alternative in community-based collaborative management in TNLL. Supporting policies and regulations at the local (village) and district level to provide assurance and certainty (including funding) through the APBDes in supporting collaborative management that begins with a special social contract to improve the economy, institutions and local resources in the community. Developing social agreement models such as the preparation of social contracts in selected villages in advance as best learning and management in collaborative management in the TNLL and could be replicated in several villages or other locations in the TNLL and other NPs in Indonesia.

\section{Akcnowledments}

During this research many parties were involved, both directly and indirectly. On this occasion the author would like to thank Haris Priyana who made the map, Akhmad Wijaya who provided a data analysis overview and reviewers who provided suggestions for improving this research. Author Contribution: Mustofa Agung Sardjono, Nur Fitriyah, Golar provided conceptually model, theoritical support and editing,

\section{References}

Abdullah. (2013). Stakeholder perspective of the delination criteria of the buffer zone in reserve conservation: the FRIM heritage site. University of Wesminster, London. https://doi.org/10.1016/j.sbspro.2013.11.064

Anonymous. (2004). Projections and Analysis Data of the Lore Lindu National Park 2004-2009. Hammer.

Anonymous. (2010). Collaboration of BBTNLL, Directorate General of Forest Protection and Nature Conservation and the Nature Conservancy. Lore Lindu National Park Management Plan 2004-2029.

Ardhian, D. (2011). The Last Tree for Orangutan-Great Apes in the Conservation and Development Vortex. The Nature Conservancy, Jakarta.

Berdej, S. (2011). Transformation of Community Conservation Agreement and their Emerging as Policy Tool for Conservation in Lore Lindu National Park Central Sulawesi. Thesis Master, Wilfried Laurel University, Canada.

Bismark, M. (2002). Integration of Conservation Interests and Needs of Community Income Sources in the Management of Conservation Areas. Prosiding, Forest Resources Rehabilitation and Conservation Research Results, P3HKA Bogor.

Bismark, M., \& Zuraida. (1997). Land Use Patterns by Village Communities Around the Forest Park Area Dr. Muhammad Hatta West Sumatra. Forest Research Bulletin, 608, 61-72.

Golar. (2014). The Conflict Resolution and Shifting Community Empowerment at Lore Lindu national Park. (In Indonesian Version). The Proceedings of the National Seminar on Forest Management Community (KOMHINDO), Hasanuddin University, Makassar 4 - 5 September 2014.

Helmi., S., Rachan, I., Sukma, T. S. (2005). Building and Strengthening a Common Ground in Natural Resource Management. Publisher FPB-TNLL., FKTNLL, TNLL., CARE., PTF ECML II, Central Sulawesi. 98h.

Indrawan, M., Primack, R. B., \& Supriatna, J. (2007). Conservation Biology. Obor Indonesia Foundation, Jakarta.

Kelso, A., \& Jacobson, M. (2010). Community Assessment Of Agroforestry Opportunities in GaMothiba, South Africa. Agroforestry System, 83, 267-278. https://doi.org/10.1007/s10457-011-9384-5

Livawanty. (2012). Problem Resolution and Prospect of Handling Tenurial Conflicts in the Dongi-Dongi Community in Lore Lindu National Park, Central Sulawesi Province. Dissertation, Mulawarman University, Samarinda.

Locke, J. (1960). An Essay Concerning The True Original, Extant and of Civil Government, In social Contracts, London. Oxford University Press.

Mallombasang, S. (2012). Study on the Development of Strategy and Conservation in the Conservation Agreement Areas of the Bobo Village Community of Lore Lindu National Park. Dissertation. Mulawarman University, Samarinda. 
Mappatoba, M. (2004). Co-management of Protected Areas. The case of Community Agreement on Conservation in the Lore Lindu National Park, Central Sulawesi-Indonesia. Gottingen: Cuvillier Verlag.

Meijaard, E., Sheil, D., ... , \& O'Brien, T. (2006). Post Harvesting Forests - Protecting Wildlife in Production Forest Activities in Kalimantan. CIFOR, Bogor.

Noer, D. (1997). Political Thought of the West Country. Bandung: Nizam.

Peluso, N. L. (2006). Rich Forest, Poor People: Resource control and resistance in Java (Translation of Landung Simatupang). Jakarta: Konphalindo and Ford foundation.

Rasyid, M. Y., \& Sambas, W. (1978). The ideals and phenomena of the Humida Tropical Forest. Pradnya Paramita, Jakarta.

Robinson, E. J. Z., Albers, H. J., \& Busby, G. M. (2013). Impact of Zone Size and Management buffers on Illegal Extraction, Park Protection and Enforcement. Ecological Economic Journal, 92, 96-103. https://doi.org/10.1016/j.ecolecon.2012.06.019

Sangaji, A., Hamdin, M., Sugiharto, Lumeno, F., \& Lahigi, S. (2004). Community and National Park lore Lindu. Kemala Foundation and the Tanah Merdeka Foundation. Hammer.

Sardjono, M. A. (1993). Cultivation - Lembo in East Kalimantan, A Model for the Development of Agroforestry Land Utilization in the Humid Tropics. Mulawarman Forestry Reports No. 7, Samarinda.

Sardjono, M. A. (1996). Strategies and Efforts to Improve Community Development Activities in the Environment of Forest Entrepreneurs in East Kalimantan. Reflection and Implementation and Future Initiatives, Samarinda.

Sardjono, M. A. (2004). The Relevance of Social Principles in Certification to Optimize the Sustainability of Forest Resources and Forestry Enterprises. Paper Presented at Workshop on "Certification of Crossing Roads: Trade Politics, Sustainability of Natural Resources and Eradication of Poverty" and Congress "Transforming LEI into Constituent Based Organizations". Jakarta. 12 h.

Schmitz, Soentoro, M. F., Matos, D. G. G., De Aranzal., Ruiz-Labourdette, P., Aguilera, P., \& Pineda, F. D. (2012). Effects of a protected area on land-use dynamics and socioeconomic development of local populations. Biological Conservation, 149, 122-135. https://doi.org/10.1016/j.biocon.2012.01.043

Winardi. (1994). Conflict Management “Conflicts of Change and Development”. Mondar Maju, Bandung.

Wyatt, S., Fortier, J. F., Natcher, D., Smith, P., \& Hébert, M. (2013). Collaboration between Aboriginal peoples and the Canadian forest sector: A typology of arrangements for establishing control and making benefits of forestlands. Journal of Environmental Management, $\quad 115, \quad$ 21-31. https://doi.org/10.1016/j.jenvman.2012.10.038

\section{Copyrights}

Copyright for this article is retained by the author(s), with first publication rights granted to the journal.

This is an open-access article distributed under the terms and conditions of the Creative Commons Attribution license (http://creativecommons.org/licenses/by/4.0/). 